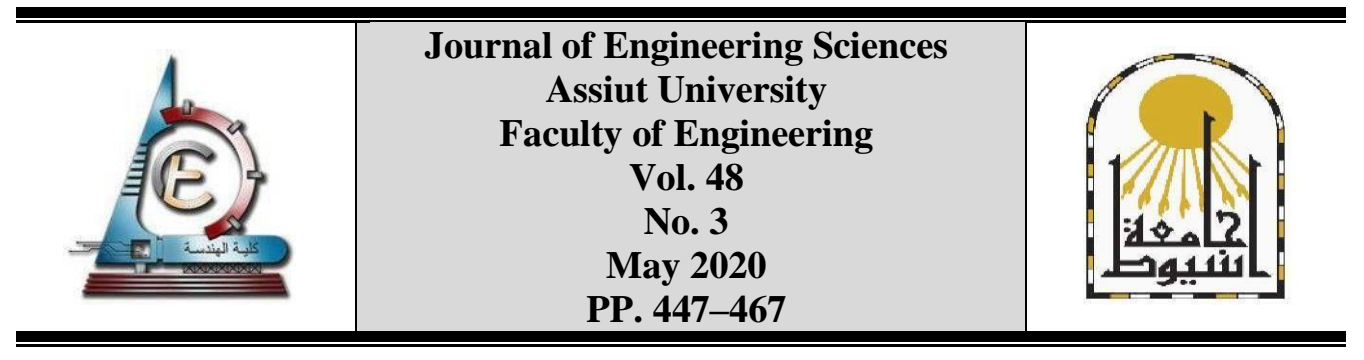

\title{
AN INTENSIVE METHODOLOGY FOR DESIGNING NEAR ZERO ENERGY PUBLIC BUILDINGS IN EGYPT, OFFICE BUILDING AS A CASE STUDY
}

\section{Rania Fouad Ismail, Zeinab Mohamed EIRazaz, Nasreen Fathy Abdelsalam}

Faculty of Engineering, Helwan University, Egypt

Received 1 December 2019; Accepted 31 December 2019

\begin{abstract}
Building sector consumes $40 \%$ of the total energy consumption worldwide. This number is much higher in Egypt. It reached 52\% of total energy sold in 2014 with an annual average growth of $5.2 \%$. Public buildings energy consumption; in turn; has a great effect on total energy consumption. In Egypt public buildings represent $40 \%$ of the Egyptian building sector. They can give a large potential in reducing total national energy demand and solve a part of energy problem in Egypt. Moreover, they can generate energy to be nearly zero energy building or even zero energy building "off grid connection buildings" in an ambitious plan. Using renewable energy techniques (such as; solar cells\& wind turbines) is also considered an optimum solution in this field.

This paper targets zero energy public building in Egypt. It suggests an intensive design methodology which based on three major phases: first- is to design an energy efficient public building, second- is to reduce the building energy consumption to the minimum, then the third- tends to produce energy and cover the building needs. To check the efficiency of the proposed methodology, an experimental study is applied on an office building model as case study of public building in Egypt. Design Builder simulation program is used to calculate and compare the building energy consumption in the three successive phases. After applying "the intensive methodology for designing zero energy public buildings" on the proposed office building model, energy consumption indicates initial energy reduction and the consumption became $245232.39 \mathrm{kWh} / \mathrm{yr}$. $(28 \mathrm{kWh} / \mathrm{m} 2$.). Once again, at the end of the consequential phases, the installed photovoltaic panels succeeded in producing 107923.2 $\mathrm{kWh} / \mathrm{year}$, and an array of 408 microwind turbines added $138964.8 \mathrm{kWh} / \mathrm{yr}$ - the sum of the energy produced comparable with the mentioned consumption conclude mathematically zero needs.
\end{abstract}

At the end, the experiment shows that becoming near zero energy building, or zero energy building, or even energy building plus can be practically true in the upcoming near future. Moreover, calculations and comparisons support using the intensive methodology in designing zero energy public building in Egypt.

Keywords: Energy Consumption, Zero Energy, Public Building, Passive Systems, Energy Saving, Energy Reduction Strategies, Design Methodology, NZEPB.

\section{Introduction}

Building sector consumes $40 \%$ of total energy consumption worldwide [1]. Energy consumption in this sector is much higher in Egypt. It reached 52\% of total energy sold in 
2014 with an annual average growth rate of 5.2\% [2]. These increasing rates affect energy cost, exhaust national grid and lead to troubles in Energy supplies. Non-domestic sector is expected to reach $33 \%$ of total energy consumption in 3030 [3], thus it represents great potential in reducing energy demands. This make it important to adopt the main aim of this scientific research which intends to introduce an applicable design methodology for public buildings to become nearly zero energy buildings or totally zero energy buildings in an optimistic case. The research believes that public buildings can assure zero energy consumption if they follow a considerable methodology in their design from the beginning. To achieve its aim, an intensive methodology is applied. Three major phases are proposed and tested: the first targets energy efficiency, the second applies energy saving strategies and the third adds renewable energy techniques. All these phases are considered equally important and complete each other. "Design Builder" software is also used to simulate energy performance after completing of each phase. Then calculations and results of each phase are compared to find out the efficiency of the proposed design methodology.

Recently, zero energy public buildings receive a great concern worldwide.

The Energy Independence and Security Act (EISA) at 2007 set a goal of Net Zero Energy (NZE) use for all public buildings by 2030. Further, it specified a Net Zero Energy target of $50 \%$ of U.S public buildings by 2040, and a net-zero standard for 100\% of new and existing public buildings by 2050 [4]. Egypt must begin its action in this field. To achieve zero energy goals" nationally as well as internationally", it is essential to follow a well-planned design methodology to guide architects, engineers, contractors and decision maker.

\subsection{Problem statement}

Delivering zero energy buildings becomes one of the most important global concerns. Many countries set they action plans. Public buildings for most of them are put in the priority. Unfortunately, zero energy design methodologies are still limited in public buildings field. In Egypt case, there is an essential need for its own action plan, and consequently an applicable design methodology for its pubic zero energy buildings is still missed.

\subsection{Scope of research}

The scope of the study is to set an applicable methodology for designing zero energy public buildings in Egypt. This study focuses on the design process to get highly energy efficient public building as a beginning, then enhance this efficiency by integrating renewable energy technologies. A simulating experiment is carried out by using Design Builder simulation program to check the ability of the proposed methodology. Research scope dose not include building construction phase or cost analysis of the proposed energy production scenarios which are beyond this study.

\subsection{Research aims and objectives}

The research main aim is to set an applicable methodology for designing zero energy public buildings in Egypt, or at least highly energy efficient public buildings as a primary step.

\subsection{The research hypotheses}

The research hypothesizes that applying proposed intensive methodology for designing zero energy public buildings in Egypt will cover public building energy demands.

Further, the integration between environmental design strategies, new techniques, and renewable energy technologies will hit zero energy goal. 
Rania Fouad Ismail et al., An intensive methodology for designing near zero energy ..........

\subsection{Research methodology}

The research methodology in brief:

\begin{tabular}{|c|c|c|c|c|}
\hline $\begin{array}{c}\text { Previous studies } \\
\text { outcomes } \\
\text { the proposed } \\
\text { model }\end{array}$ & $\begin{array}{c}\text { Reduction } \\
\text { Strategies+ Run } \\
\text { the "Design } \\
\text { Builder" Software }\end{array}$
\end{tabular}$\longrightarrow \begin{gathered}\text { Calculations } \\
\text { \&Comparisons } \\
\text { Optimum Design }+ \\
\text { Energy production }\end{gathered}$

\section{Literature review}

Several researches and studies are revised in this section, involving; terminologies climatic strategies, efficient design, passive design, building activities, public buildings systems and renewable technologies. The research proceeds afterward upon the solid base of these studies' outcomes.

\subsection{Public buildings definitions}

Public buildings at United States government is building that funded through tax money by the U.S. government or state or local governments [5], while United Kingdom defines "public building" as a building that is occupied by a public authority and frequently visited by the public [6], on the other hand, Egypt and United Arabic Emirates define "public building" as the non- residential building, private or government building[7], finally, "public building" can be defined as any non-residential building, no matter it owned by government or people.

\subsection{Zero \& Nearly Zero Energy public building definitions}

Zero Energy Building (ZEB) was descripted at the National Renewable Energy Laboratory (NREL) as "An energy efficient building where, on a source energy basis, the actual annual delivered energy is less than or equal to the on-site renewable exported energy"[8], while the New Buildings Institute (NBI) defines Zero Net Energy (ZNE) by: "The amount of energy provided by on-site renewable energy sources is equal to the amount of energy used by the building"[9]. Also, the NSERC Smart Net-zero Energy Buildings Strategic Research Network (SNEBRN) define the net zero energy building (NZEB) by "It is the building that in an average year, produces as much energy (electrical plus thermal) from renewable energy sources as it consumes" [10]. And European Commission definition for Nearly zero-energy buildings NZEB is "A building that has a very high energy performance with the nearly zero or very low amount of energy required covered to a very significant extent by energy, from renewable sources produced on-site or nearby" [11]. Therefore, it is concluded that the Zero energy public building (ZEPB) is:" A public building that designed with high energy efficiency and has renewable resources to produce energy, and the total building energy consumption is less than or equal the total amount of renewable energy produced on an annual basis" (Author).

\subsection{Climate effect on public building design strategies}

Climate is a critical variable in the design of a NZEB projects. [12]. Three important factors show the serious effect of climate on ZEPB. (Fig. 1)

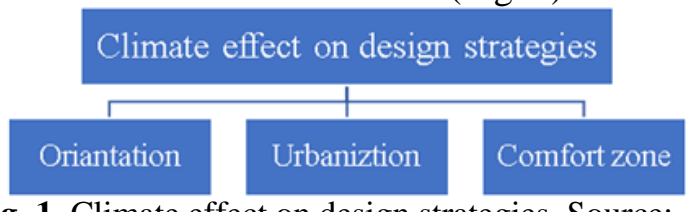

Fig. 1. Climate effect on design strategies, Source: Author 
Public building orientation refers to the way a public building is situated on a site and the positioning of windows, rooflines, and other features [13] and orientation of building should interact with the climatic zone. And the urbanization effect cause of dense building, heat emissions, human activities, etc., which has a great impact upon the local climate of a city, there is great difference in temperatures between urban and rural areas and this is called as urbanization effect or the urban heat island (UHI) effect. Also, achieving comfort zone is very important element in ZEPB design process [12]. General factors affect ZEPB comfort design is shown in (Fig.2).

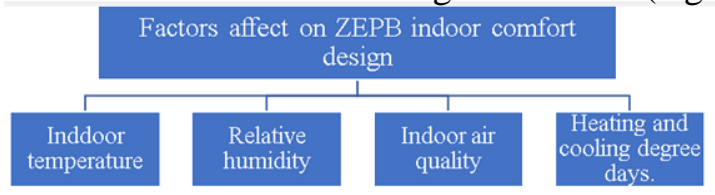

Fig. 2. Factors effect on ZEPB indoor comfort design, Source: Author

\subsection{Factors of public building energy efficiency design}

Factors that increase public building energy efficiency envelop like wall section design, glazing and opening control, roof insolation, and more need to be carefully studied. In addition, passive strategies for heating, cooling, ventilation, daylighting and shading need to be applied to reach high energy performance building. High performance building envelope is the first step and the critical element towards ZEPB building design [14]. Because environmental conditions are so variable, the task of the public building envelop is dynamic, modifying, and stabilizing the available energy flows [12]. So, each element needs to be studied in detail to save energy, starting from fabrics U-value, openings, shadings design, ending by roofs.

\subsection{Passive design strategies in public buildings}

'Passive design' is design that takes advantage of the climate to maintain a comfortable temperature range in the building. Passive design reduces or eliminates the need for auxiliary heating or cooling [15]. The building type and operation determine which strategies will have the best overall impact on energy performance. There are many passive design strategies, but for ZEPB design the most important strategies are passive heating, passive cooling, passive ventilation, and passive day lighting (Fig. 3).

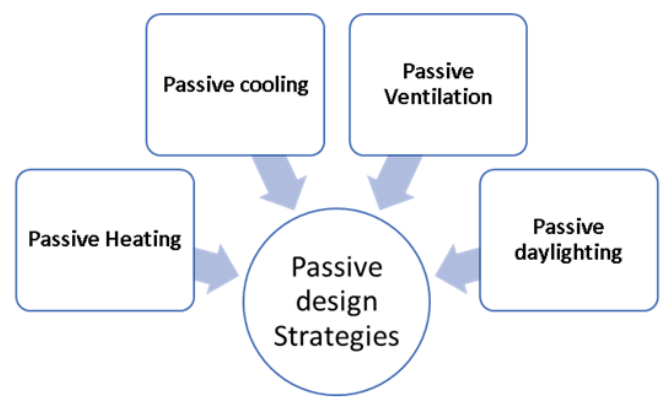

Fig. 3. Passive design strategies, Source: Author

\subsection{Building activity effect}

There are many factors effecting on public building energy consumption like; the building activity, number of occupancies, the operating hours, building equipment, the form of cooling source, the age of construction, the form of heating source and the number of building stories [16]. 
Rania Fouad Ismail et al., An intensive methodology for designing near zero energy ..........

\subsection{Technical systems and building equipment in public buildings}

Technical systems and building equipment are the great energy consumption at public buildings. Technical systems like; the heating and hot water systems which include the corresponding heat sources, the ventilation system, the cooling system, lighting and the systems which generate heat or electricity locally, any system must be included in the energy calculation [17].

\subsection{Renewable Energy production in public building}

Many countries are planning for all public buildings to be net zero by 2030, this can be achieved by producing as much energy onsite as they consume over a year as in California according to their Energy Code requirements [18].

Zero energy public building need to be designed as off Grid Connection building, by using renewable energy system that is energy generated from renewable energy sources like sun, wind, or other natural processes, and not connected to the utility grid. This system will generally have a battery bank to store the electricity for use when needed [17]. The renewable energy resources used most probably in public building are photovoltaic and wind energy.

\subsubsection{Photovoltaic techniques}

The annual effective solar irradiance varies from 60 to $250 \mathrm{~W} \mathrm{~m}^{2}$ worldwide [19]. Currently, new technologies are being employed to generate electricity from harvested solar energy [20]. The efficiency of solar power technologies has increased greatly in recent years. There are many types of solar cells based on the material used but Multicrystalline solar cells are the most common type in PV market, also, photovoltaic glass uses the same basic principle as solar panels, but it is transparent [21].

\subsubsection{Wind energy, building integrated turbines}

Wind turbines proved its efficiency in producing electricity due to the recent technological improvements [22]. There are many wind turbine types and different sizes [23]. One of the latest technologies in wind turbines is the Micro wind turbine because it uses low wind speeds, light weight components, has a modular structure and can be optimized for different conditions and wind sites. Thus, the swept area can be adjusted according to the requirements (Fig. 4, 5).

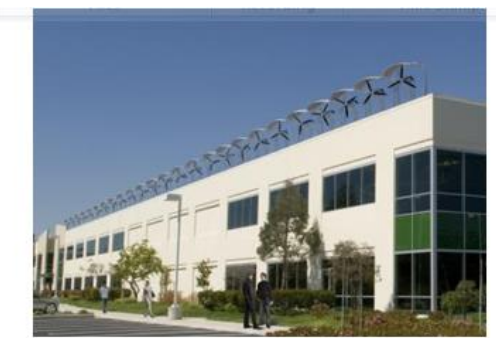

Fig. 4. Integrating micro wind turbines to public building, Source: [33]

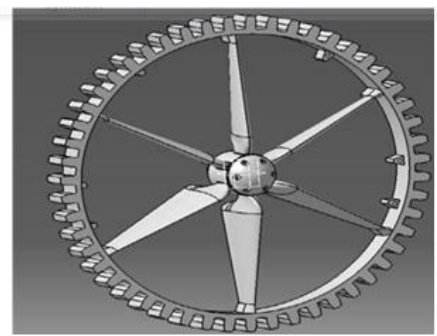

Fig. 5. Concept design of micro wind turbine, Source: [34]

\subsection{Public buildings control systems}

Public building control systems BCSs are critical to the operation of high-performance zero energy buildings. Smart public building controls provide advanced functionality through a computerized, intelligent network of electronic devices designed to monitor, control and optimize building services, such as, lighting, HVAC, electrical plug-loads, security, access control, audio-visual, as well as occupancy-related systems [24]. 


\section{Proposed design process}

The research proposes and follows the shown design process in finding its prototype:

- First, defining the program through the building design standards, building information, location, getting the climate data.

- Then, sketch the building design that adopt energy reduction strategies, in this stage 3D building model will be built after estimating the spaces, building shape, openings glazing methods, natural daylighting and ventilation techniques, walls and roof insulation and specify the best orientation.

- The third stage is running an energy simulation to estimate the building energy needs and set the design conditions for the design.

- The Forth stage is getting full concept design by integrating renewable energy resources to the building design to cover the building energy needs.

- Finally, reaching coordinated ZEPB design. (Fig. 6)

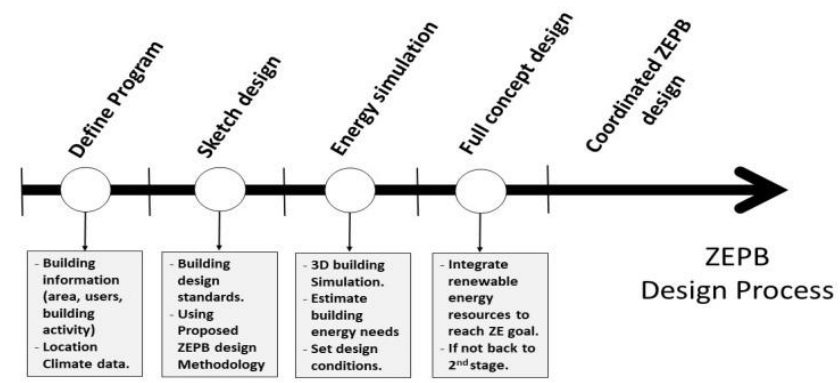

Fig. 3. ZEPB Design process, source: Author

\section{Empirical part}

The Empirical section depends on virtual model which is designed according to the above-mentioned process. The main purpose of this model is to test experimentally the ability of the proposed intensive methodology design in achieving NZEPB in Egypt, and/or modify it if needed. The proposed building is chosen to be a local office building - as an example of public buildings- as there are many office buildings succeeded to reach the zero energy internationally [25]. Location is chosen to be in capital Cairo, Egypt, that hosts great number of office buildings. The proposed building is set to be a five-story height. It consists of U\&L shaped standard unites. These two units can be repeated within unlimited shapes, stories, and sizes. The experimented model is one of them. The research point of view is to run its experiment on an inconstant form to assure widen the results.

The empirical part passes through three phases:

$1^{\text {st }}$ phase- design the prototype according to building function needed, the passive design basics and environment criteria to be the model base case

$2^{\text {nd }}$ phase- apply different reduction strategies, then three main strategies "case1, case2, case 3 " are chosen to test and record their performance.

$3^{\text {rd }}$ phase- add renewable energy techniques to produce energy, and mark the final energy performance

Normally, the methodology efficiency for finding optimal building configuration is demonstrated when presenting by test case [26]. And the article test case full design details and criteria are as follow: 
Rania Fouad Ismail et al., An intensive methodology for designing near zero energy ..........

\subsection{Office building prototype design}

In this part, the office building prototype is designed in accordance to the site analysis, specific needs and the passive design strategies.

\subsubsection{Site analysis}

Climate is the first aspect considered. It is a critical variable in the design of a NZEPB; it can influence the whole Building envelope by the effect of the temperature, humidity, wind, and sun. Egypt located in the hot arid climatic region, so the research detect the building design strategies in Cairo by using Climatic Consultant program and importing Cairo weather files into it, the program shows in a psychometric chart the most important strategies that can be applied in designing the building as using high thermal mass, natural ventilation, and sun shading as shown in (Fig. 7). Also, the program provides the wind wheel which identifies the preferable wind direction that will affect the selection of the building orientation. It also indicates the best orientation for the building to be the north direction.

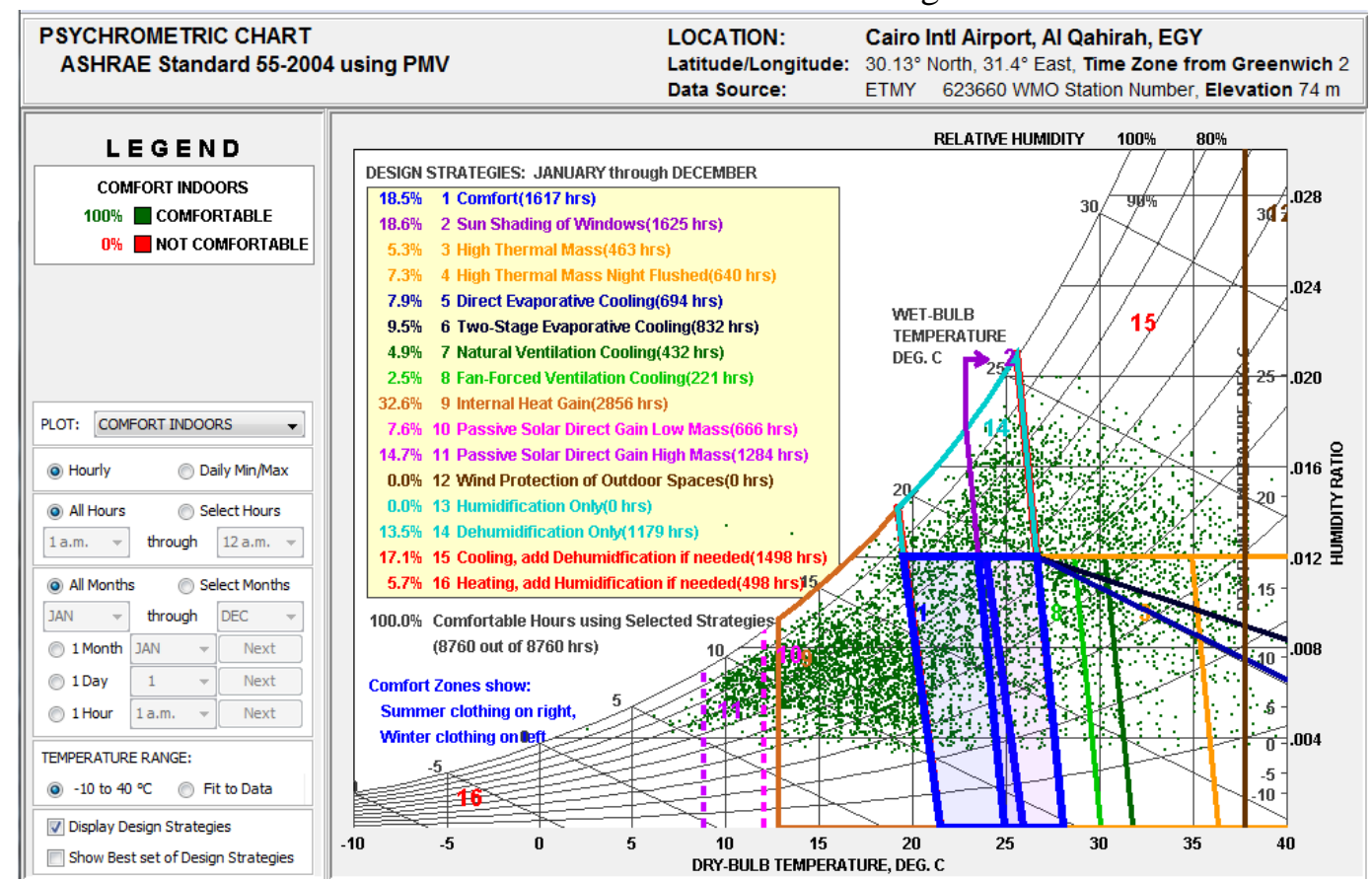

Fig. 4. psychrometric chart and wind wheel from climatic consultant program source: author

\subsubsection{Apply flexible design program}

The design program for the proposed office building considered several space types to meet the needs of staff and visitors, these include: offices (open space, semi closed, closed space), conference rooms, meeting rooms, reception, support spaces like (filing space, storage space, print and copy area), cafeteria, toilets, general storage, computer/information technology (IT) closets, maintenance closets.

\subsubsection{Energy design treatments}

Due to the hot, arid climate of Egypt, the design in this stage works upon enhancing self-shading building and traditional treatments. The main target here is to design zero energy office building with low energy needs, so using the environmental features; such as enhancing natural ventilation through using vertical courtyards \& wind catchers and using self-shading \& extra are considerable. 


\subsubsection{Form design concept}

Office space unit is designed as typical $U$ shape or $L$ shape prototype to achive the best results for daylighting and natural ventlation, and to fit a uniform structure grid, as shown in (Fig. 8,9)

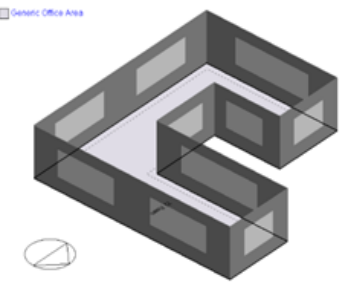

Fig. 8. Typical U shape, source: author

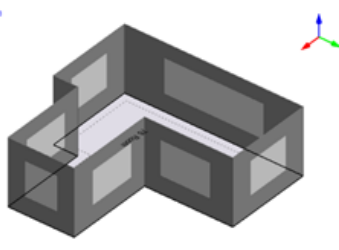

Fig. 9. Typical L shape, source: author

The design gives flexibality by distributing its $\mathrm{U}$ and $\mathrm{L}$ shapes, which are connected horizontally to form courtyards and interactive outdoor spaces, and vertically to create dynamic vertical courtyards and self-shaded masses as shown in (Fig. 10,11). this interactive distribution is created to get the best results from shading and natural ventilation, in addition, to increase the exposure of the external surfaces to daylighting as shown in (Fig. 12,13).

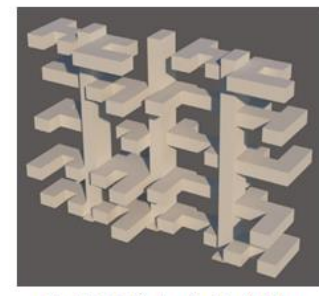

Fig. 10. Distributing the $U$ and $L$ shape vertically and horizontally, source: author

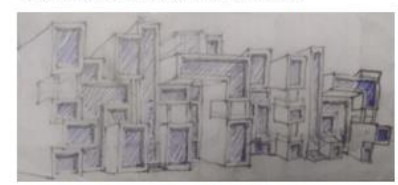

Fig. 12. Office building north facade proposal freehand sketch, Source: Author
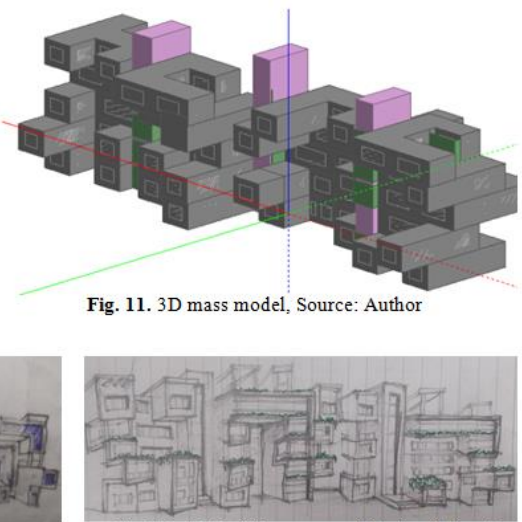

Fig. 13. 3D building proposal freehand sketch, Source: Author.

The building design grid is also stated to be module of $4 * 4 \mathrm{~m}$ to construct the building with simple beam concrete structure system as shown. This structured system was chosen as a functional\& economical choice and locally available technic in Egypt (Fig. 14).

\subsubsection{Office building plans}

The final proposed office building plans are finalized and approved to go forward in simulation process and the upcoming phases as shown in (Fig. 15, 16, 17, 18, 19) 
$\mathbf{N}$

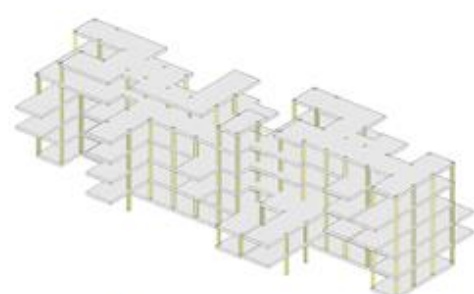

Fig. 14.Building construction is based on simple beam system, Source: Author

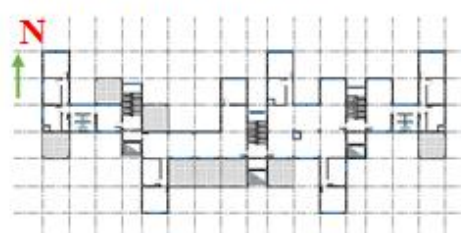

Fig. 16. Office building proposed first floor plan, Source: Author

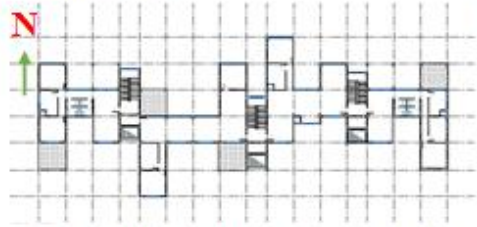

Fig. 18. Office building proposed third floo plan, Source: Author

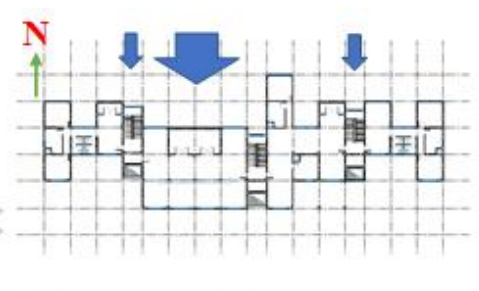

Fig. 15. Office building proposed ground floor plan, Source: Author

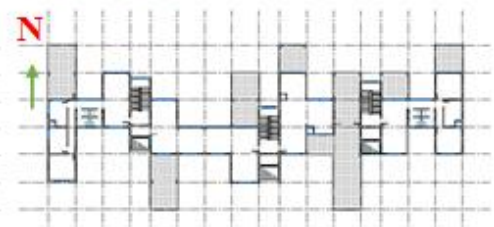

Fig. 17. Office building proposed second floor plan, Source: Author

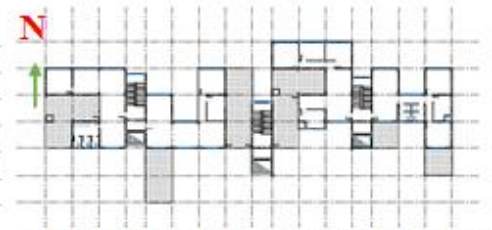

Fig. 19. Office building proposed fourth floor plan, Source: Author

\subsubsection{Total building information}

All information is precisely defined and get ready to process into the next step, the following table represents a brief description of the proposed building.

Table 1.

Brief description of the proposed office building, Source: Authors

\begin{tabular}{|l|l|}
\hline Location & Egypt, Cairo \\
\hline Climatic zone & Hot arid \\
\hline Building type & Office building \\
\hline Orientation & North \\
\hline Floor area & $500-700 \mathrm{~m}^{2}$ \\
\hline Building area & $2286 \mathrm{~m}^{2}$ \\
\hline Design grid & $4 * 4 \mathrm{~m}$ \\
\hline Structure system & Simple beam-concrete structure \\
\hline Working hours & $8: 00$ a.m. $-4: 00$ p.m. \\
\hline People capacity & 200 \\
\hline Building state & Concept design \\
\hline
\end{tabular}

\subsection{Office building prototype modeling}

Building modeling and energy simulation is an important step that follow the Initial design of NZEPB. In this step the designer can test and choose the best reduction strategies for the predesigned building envelop and the service systems. In this stage, several design options can be evaluated and compared to get the best results.

\subsubsection{Building model in the energy simulation program}

The proposed office building design is modeled by Revit Autodesk program (Fig. 27), then integrated directly into Design Builder program. 


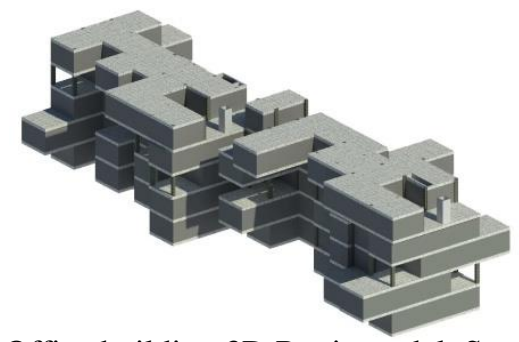

Fig. 5. Office building 3D Revit model, Source: Author

The reason of choosing "Design Builder" is its ability of predicting the building energy consumption, creating virtual environment where the operation of Heating, Ventilation and Air Conditioning (HVAC) system and lighting energy consumption of the whole building can be studied in detailed. Factors that affect building energy performance and thermal comforts of the occupants during summer and winter can be identified, and this simulation will lead to evaluate whole building annual thermal performance and retrofit decision making.

\subsubsection{Design Builder calibration}

Since, the Plug loads are the major contributor to the building's overall energy consumption, Therefore, power consumption is usually an important input for load calculations. Moreover, weekday and weekend power consumption profiles are recently received a great regard and continuous developing for the most used office equipment [29]. So, to assure the outcome results of the used software, a brief comparison was made between definite set of equipment that planned to be used in the Office building, Manually and by using the software program. The total equipment energy consumption by manual calculation gives 57,565 w/year as shown in the following (Table 1).

Table 1.

Equipment energy consumption

\begin{tabular}{|c|c|c|c|c|}
\hline & & & & \\
\hline \multirow[t]{3}{*}{ Reception } & Computer & 2 & 300 & \multirow[t]{3}{*}{1,050} \\
\hline & Printer & 1 & 200 & \\
\hline & Fax machine & 1 & 250 & \\
\hline \multirow[t]{2}{*}{ Offices } & Computer & 10 & 300 & \multirow[t]{2}{*}{3,600} \\
\hline & Printer & 3 & 200 & \\
\hline \multirow[t]{2}{*}{ Meeting room } & Computer & 3 & 300 & \multirow[t]{2}{*}{1,500} \\
\hline & Projector & 3 & 200 & \\
\hline \multirow[t]{2}{*}{ Work space } & Computer & 30 & 300 & \multirow[t]{2}{*}{10,000} \\
\hline & Fax machine & 4 & 250 & \\
\hline Copy and printer space & Printer & 5 & 1400 & 7,000 \\
\hline \multirow[t]{2}{*}{ Conference room } & Computer & 1 & 300 & \multirow[t]{2}{*}{615} \\
\hline & Projector & 1 & 315 & \\
\hline \multirow[t]{2}{*}{ Support space } & Computer & 4 & 300 & \multirow[t]{2}{*}{2,000} \\
\hline & Printer & 4 & 200 & \\
\hline IT office & Computer & 4 & 300 & 1,200 \\
\hline \multirow[t]{2}{*}{ Control room } & Computer & 2 & 300 & \multirow[t]{2}{*}{2,200} \\
\hline & Screen & 8 & 200 & \\
\hline \multirow[t]{3}{*}{ Cafeteria } & Microwave & 6 & 1200 & \multirow[t]{3}{*}{28,400} \\
\hline & Boiler & 6 & 3000 & \\
\hline & Coffee maker & 4 & 800 & \\
\hline \multicolumn{4}{|c|}{ Total equipment energy consumption (kWh/year) } & 57,565 \\
\hline
\end{tabular}

On the other hand, the simulation program equipment energy consumption indicates 46,193.97 kWh/year. The difference in the calculation was due to specifying the working hours and extract the weekends and holidays from the total. 
Rania Fouad Ismail et al., An intensive methodology for designing near zero energy ..........

\subsection{Energy reduction strategies}

This step focuses on improveing thermal comfort in the proposed office building prototype and minimizing the building energy consumption as much as possible, and concerns with the building envelope and all its elements (walls, openings, roof, shadings), in addition to stating its service systems. Several alternatives in this phase are tried and measured.

\subsubsection{Building envelop energy reduction alternatives}

The overall idea behind this part is: increasing the $\mathrm{R}$ value ${ }^{1}$ for building's walls, openings, and roof, to increases the building thermal resistance, and help in reducing building energy consumption.

\subsubsection{External walls}

Several trials were experimented within the simulation program to get the optimum energy reduction. Results were as follow; the effect of regular $25 \mathrm{~cm}$ thickness brick external wall (RValue $=2.4)$ and double $12 \mathrm{~cm}$ thickness brick walls filled with air $(\mathrm{R}-$ Value $=3.3)$ do not affect the building performance and the building energy consumption is not reduced. Then, other external wall cross section consists of doubled brick wall $12 \mathrm{~cm}$ thickness each and filled with thermal insulation sheet $5 \mathrm{~cm}$ thickness $(\mathrm{R}-\mathrm{Value}=19.5)$ as shown in (Fig. 20), and the walls are painted with white and light colors to reflect the heat is tried. This last try achieved better results. Morover, it is recommended to use rice straw compact sheet as a wall thermal insulation, due to its high resistance value [27]. Also, Green walls are advocated to be used in southern, eastern and western facades to reduce the thermal load on the external walls.

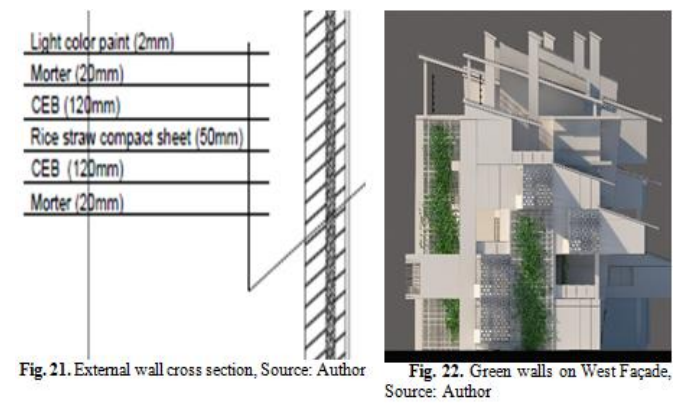

\subsubsection{External Openings}

By comparing; one single layer glass window $(\mathrm{R}-\mathrm{Value}=1.2)$, double glazed fill with air $(\mathrm{R}-$ Value $=3.27)$, and the double glazing fill with argon gas $(\mathrm{R}-\mathrm{Value}=4.08)$, the last succeed to reduce the amount of heat transmitted into the building and achieve best energy reduction results. Also utilizing high-performance glazing with a low-E coating on the inner side (RValue $=4.56$ ) helps in reflecting heat back out the building as shown in (Fig. 22).

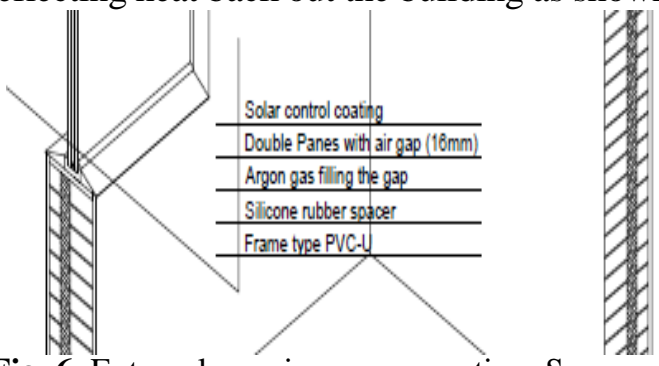

Fig. 6. External openings cross section, Source: Author

\footnotetext{
${ }^{1}$ R-Value measures: resistance against heat flow through a given thickness of a material (such as insulations- the higher $\mathrm{R}$ the better insulation properties) [35]
} 


\subsubsection{Roof design}

The roof is covered by incline surface $35^{\circ}$. Green roof is also tried. It reduces heat transfer through the roof cross section and ambient temperatures on the roof surface are as shown in (Fig. 23). The components of the used green roof $(\mathrm{R}-\mathrm{Value}=26.4)$ are of $70 \mathrm{~mm}$ structural deck, $20 \mathrm{~mm}$ waterproofing, $5 \mathrm{~mm}$ protection layer board, $30 \mathrm{~mm}$ drainage layer, $5 \mathrm{~mm}$ filter layer, and 80-150 mm lightweight soil.

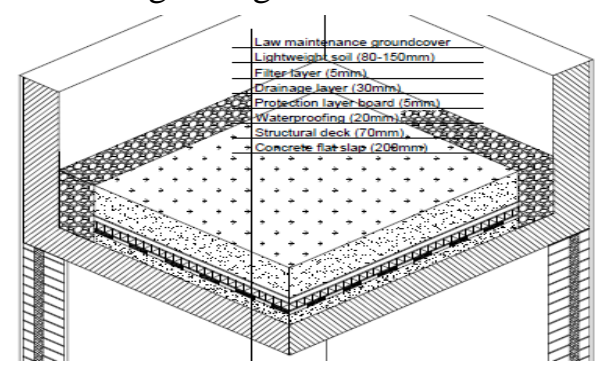

Fig. 7. Green roof cross section, source: Author

\subsubsection{Shadings elements}

To reduce energy consumption and save energy, many types of shading devices are compared then used at different façade; horizontal and $35^{\circ}$ inclined shades in the south façade, vertical shading device semi open in the eastern and western facades to allow light but not heat, also building masses are designed to make shading in the facades as shown in (Fig. 24).

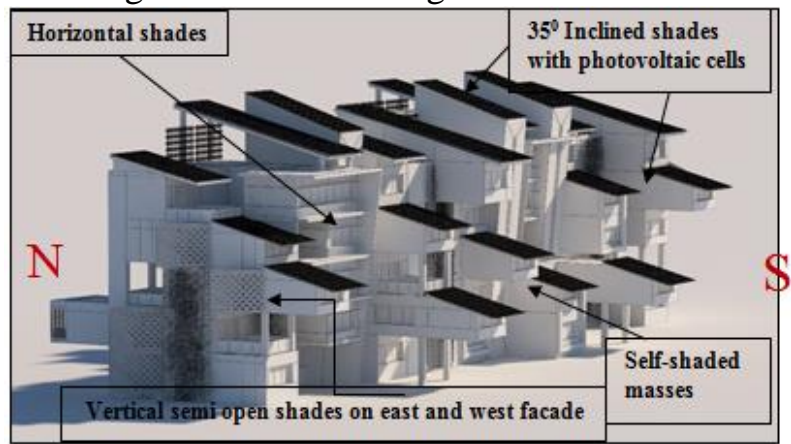

Fig. 8. Building shades types at southern and western facades, source: author

\subsubsection{Service systems at the office building design}

Service systems are also considered in this step. Ventilation system, lighting system, HVAC, and building Equipment.

\subsubsection{Ventilation system design}

Natural ventilation strategies are maximize. Building orientation was previously considered. Wide openings are placed in the north façade to get a large amount of preferable air. Wind catchers are added to ventilate the spaces that not orientated to the north direction. Both wide opening and wind catchers make cross ventilation to facilitate the flow of air inside the building as shown in (Fig. 25), vertical courts with green elements and wind catchers are used to move the air across the building and give a good ventilation and view to the surrounding spaces as shown in Fig. (26). Simulation calculations are subsequentially improved in return. 


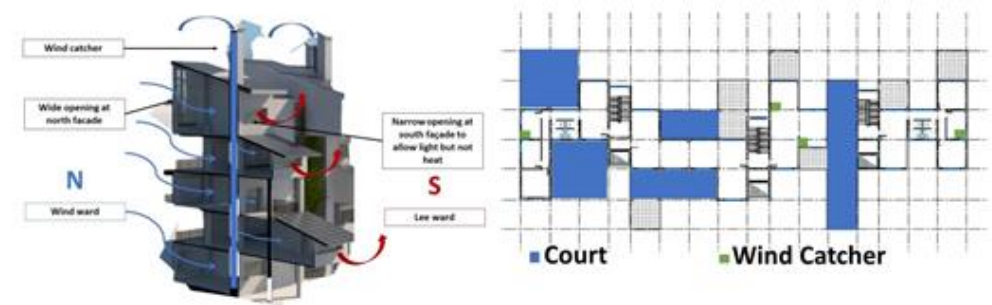

Fig. 26. Section shows the ventilation flow in the Fig. 27. Plan shows the location of the wind proposed office building design, Source: Author catcher and courts, Source: Authors

\subsubsection{Lighting system design}

Most of offices now depend on natural light in the day in addition to an efficient artificial lighting system such as LED by night. These applications gave good results in energy saving field and reducing building energy consumption.

\subsubsection{HVAC system at the office building design}

After some trials, A four-pipe fan coil unit is recommended to be used in the building HVAC system. It consists of a fan, chilled water-cooling coil, hot water heating coil, and air filter. Fan coil units provide conditioned air to the area served by recirculating space air through the coils [28].

\subsubsection{Equipment}

Equipment are furnished and set to the necessity. And according to the supposed changeless in this case, plug loads as mentioned before is calculated manually and by the simulation program to give a definite energy consumption $46,193.97 \mathrm{kWh} / \mathrm{yr}$.

\subsection{Main simulation processes (base case, case 1, 2, 3)}

The above reduction strategies are taken into consideration. Some are merged, and energy simulations process passed through four stages. Base case was simulated without any energy reduction modifications, case 1 was simulated after insulating the whole envelop, case 2 was after shadings added on, and case 3 integrated all the reduction strategies.

\subsubsection{Office building base case}

In this simulation process, the external walls thickness is $25 \mathrm{~cm}$ brick, openings have regular single layer glass, roof has regular insulation layers and no shadings are added. Also, fluorescent lighting is chosen for internal lighting. And traditional HVAC system is used.

Simulation results that the building energy consumption without applying any reduction strategies is $350103.99 \mathrm{kWh}(153.15 \mathrm{kWh} / \mathrm{m} 2)$ - in details:

- Heating (heating 8723.55, water system 2498.63 ) 11222.18 kWh

- Cooling 210742.08 kWh

- Lighting $78968.94 \mathrm{kWh}$

- Equipment $49170.79 \mathrm{kWh}$.

\subsubsection{Case 1: building envelop insulation (walls, openings and roof)}

After changing the external walls cross section to accommodate the best insulation type indicated from the previous section, and changing openings to double glazed fill argon gas, the total building energy consumption gives $329945.39 \mathrm{kWh}(144.33 \mathrm{kWh} / \mathrm{m} 2)$ with $5.75 \%$ reduction comparable with the base case(Fig. 28) - in details:

- Heating (heating 3255.07, water system 2359.5) $5614.57 \mathrm{kWh}-50 \%$ reduction.

- Cooling 203944.35 kWh the change caused - 3.2\% reduction. 
- Lighting $74192.50 \mathrm{kWh}$ the change caused $-6.0 \%$ reduction.

- Equipment $46193.97 \mathrm{kWh}$ the change caused also - $6.0 \%$ reduction.

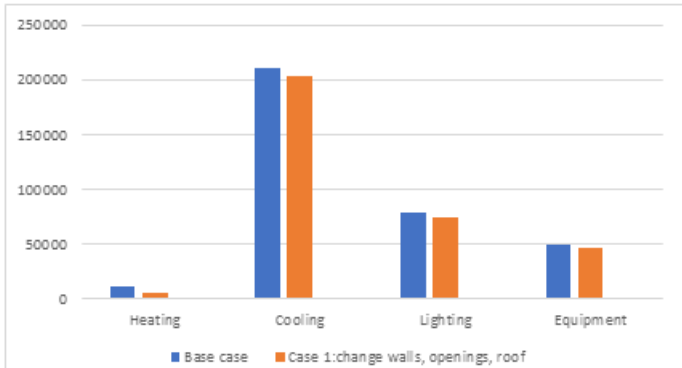

Fig. 9. Difference in energy consumption between Base case and Case1, Source: Author

\subsubsection{Case 2: shadings add-on}

By adding horizontal shadings on the base case, the total energy consumption is 319049.37 $\mathrm{kWh}(139.57 \mathrm{kWh} / \mathrm{m} 2)$ with $8.87 \%$ reduction in energy consumption (Fig. 29) - in details:

- Heating (heating 10907.32, water system 2498.63) 13,405.95 kWh - 16.28\% increase in heating energy consumption.

- Cooling 177,500.69 kWh the change caused $15.77 \%$ reduction.

- Lighting 78,968.94 kWh the change caused no energy reduction.

- Equipment 49,170.79 kWh the change caused also no reduction.

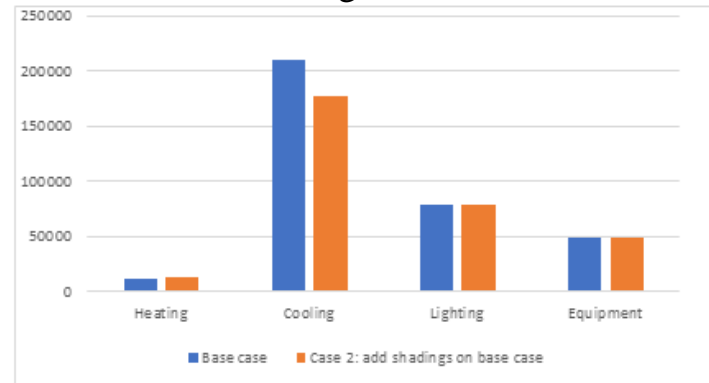

Fig. 10. Difference in energy consumption between Base case and Case2, Source: Author

\subsubsection{Case 3: complete integration of energy reduction strategies}

After integrating the whole reduction strategies, the building energy consumption becomes $245232.39 \mathrm{kWh}(107.28 \mathrm{kWh} / \mathrm{m} 2)$ with $30 \%$ reduction in energy consumption (Fig. 30) - in details:

- Heating (heating 7420.10, water system 601.23) 8021.34 kWh 28.52\% reduction.

- Cooling $153920.83 \mathrm{kWh}$ the change caused $26.96 \%$ reduction.

- Lighting 37096.25 kWh the change caused 53.02\% reduction.

- Equipment $46193.97 \mathrm{kWh}$ the change caused also $6.0 \%$ reduction.

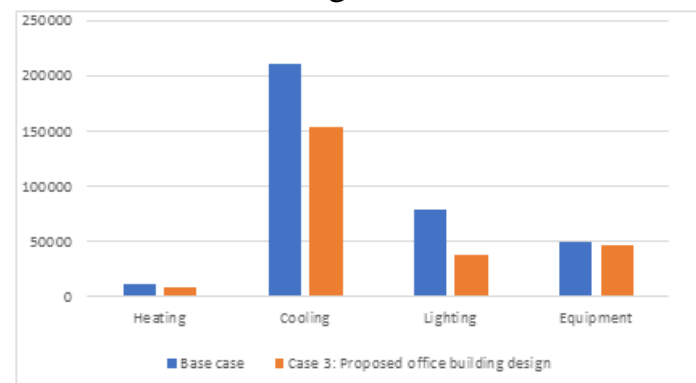

Fig. 11. Difference in energy consumption between Base case and Case3, Source: Author 
Rania Fouad Ismail et al., An intensive methodology for designing near zero energy ..........

\subsubsection{Cases results comparison}

Cases simulation comparison ended that: when integrating the whole available reduction strategies to the initial proposed design, energy consumption reduces by $28.52 \%$ compaerable with the base case (Fig.32)

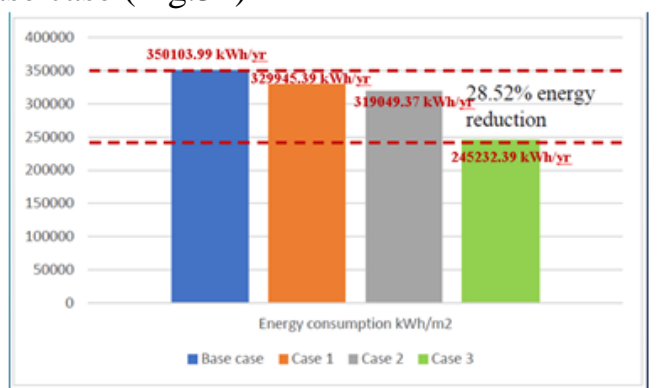

Fig. 12. Comparison between all cases in total energy consumption, Source: Author

The research case study by the end of this phase achieves energy consumption of $245232.39 \mathrm{kWh} / \mathrm{yr}$., after using the chosen reduction strategies.

The experiment in details shows that; Insulating the building envelop can save up to $5.75 \%$ from the total energy consumption, adding shadings on the building openings can save up to $8.87 \%$ from the total energy consumption, integrating energy reduction strategies together can reduce the energy consumption by $28.52 \%$.

\subsubsection{International consumption Comparison}

In Europe, energy consumption for public building is estimated to $280 \mathrm{kWh}$ per square meter [36], in USA and Canada the analysis found that the energy consumption of non-certified buildings could be minimized to $159 \mathrm{kWh} / \mathrm{m} 2$ and in certified buildings (LEED, BREEAM), the average electricity consumption per square meter is $150 \mathrm{kWh} / \mathrm{m} 2$. In the research case study, base case energy consumption reaches $153.15 \mathrm{kWh} / \mathrm{m} 2$, at (case 1) it is $144.33 \mathrm{kWh} / \mathrm{m} 2$, at (case 2) it is $139.57 \mathrm{kWh} / \mathrm{m} 2$, while (case 3 ) hits $107.28 \mathrm{kWh} / \mathrm{m} 2$. (Fig. 31). So, it worth to be at the $1^{\text {st }}$ success step guide towards zero energy public buildings in Egypt, especially when comparing with an approximately similar climate of some areas mentioned in the figure below.

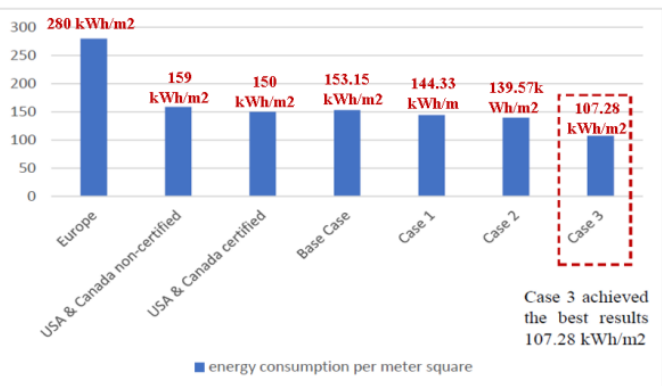

Fig. 13. International Energy consumption rates and practical study, Source: Author.

\subsubsection{Simulation results favor analysis}

Due to its best outputs in energy consumption, case 3 simulation results are analyzed to get the main factors that can be managed in future and achieve better results.

Table2 shows some of these strong effective factors, which can be summarized in the followings: -

- The most effective factor on energy consumption is the cooling factor. So, it worth to find out more solutions for this factor. 
- Air, Radiant and Operative temperature are relatively convergent in affecting thermal comfort, and subsequently energy consumption.

- Solar gains from exterior windows are intensively affecting energy consumption. Computers\& equipment and general lighting come later.

- "Monthly energy consumption" indicates all factors changes, which can be considered separately in extra reduction cases.

- For more illustration, Energy consumption for cooling- as an example- increases dramatically from May to October. Within simulation process, it is estimated to increase by; 414\%, 660\%, 939\%, 1000\%, 760\%, 575\% respectively based on January consumption. So, more efforts and extra solutions can target this period and give further dimensions in reducing energy needed.

Table 2.

Case 3 DesignBuilder results, Source: Author

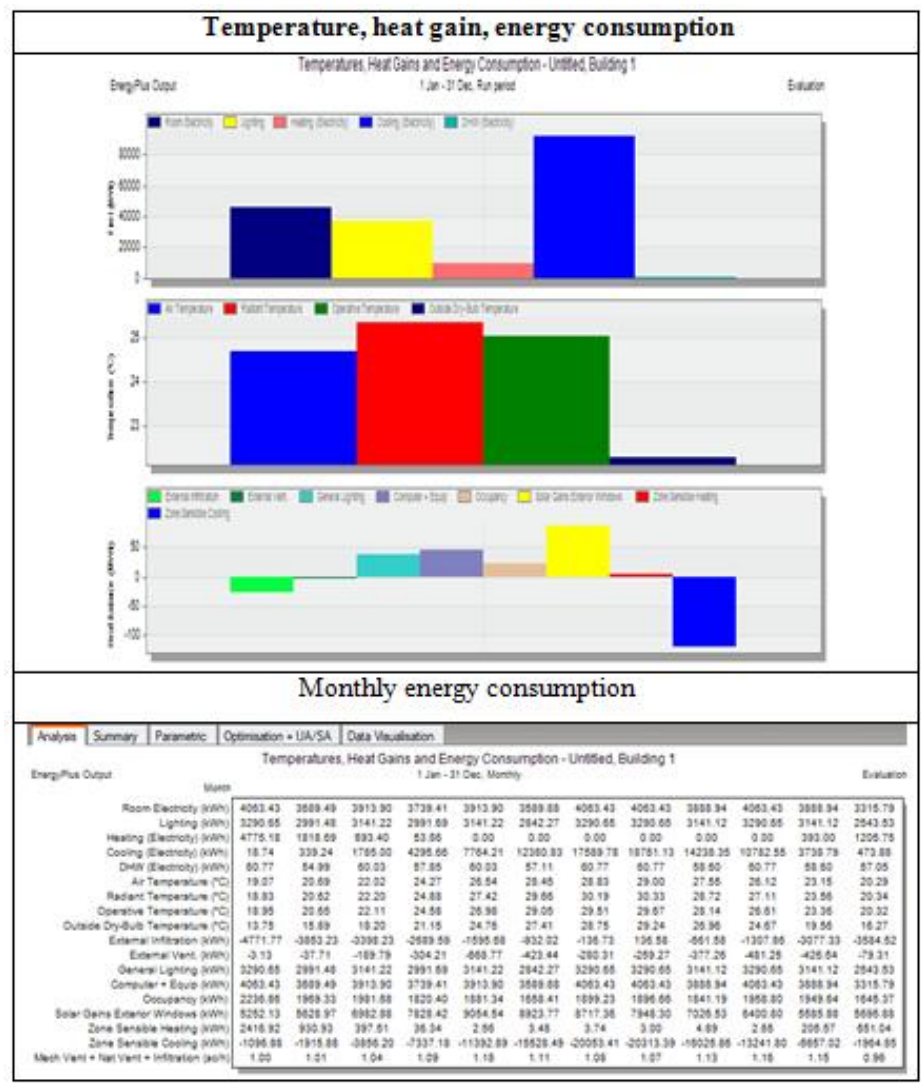

\subsection{Energy production}

One more step can be added to the design methodology of building NZEPB, which is energy production. It was obvious that case 3 with its $245232.39 \mathrm{kWh} / \mathrm{yr}$. energy consumption is the minimum among the stated alternatives. But zero energy target has not achieved yet. In this step, renewable energy resources are added to the office building prototype design to produce its own energy (less or more). Solar photovoltaic cells and micro wind turbines techniques are integrated with the designed envelope to complete the task. 


\subsubsection{Solar energy techniques}

As it is a nowadays wide spread techniques, solar heaters are suggested to supply hot water to the building. This techniques promots energy consumption reduction. The heaters sunlight strikes are placed on the roof face the south direction and the water storage tanks are placed in the basement. $\mathrm{AP}^{*} 30$ solar collector [30] can be used to produce $300 \mathrm{~L}$ of hot water, As the office building consist of 5 story and serve 200 person so 3 solar water heater can be installed to serve the whole building.(Fig. 33,34).
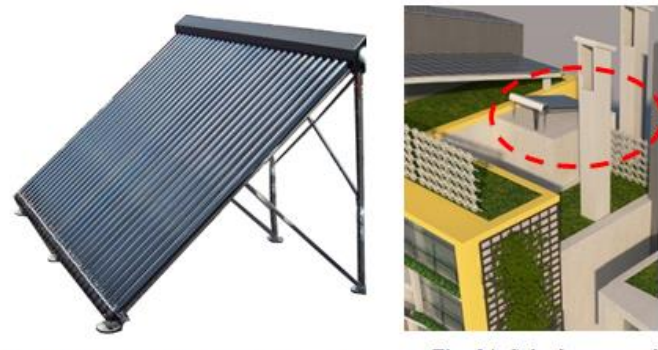

Fig. 33. Solar water heater unit, source: [37]

Fig. 34. Solar heater on the roof source: Author

Photovoltaic cells are also advocated to be used in the office building prototype as energy producers this time. To calculate the number of PV panels that suit covering the inclined roof \& south façade (Fig. 35), and estimate the electricity generated, the global formula is used $\{\boldsymbol{E}=\boldsymbol{A} * \boldsymbol{r} * \boldsymbol{H} * \boldsymbol{P R}\}$ [31].

$\boldsymbol{E}=$ Energy $(\mathrm{kWh}), \boldsymbol{A}=$ Total solar panel Area $\left(\mathrm{m}^{2}\right)=448 \mathrm{~m} 2, \boldsymbol{r}=$ solar panel efficiency - for Monocrystalline solar panels (Mono-Si) $\mathrm{r}=20 \%, \boldsymbol{H}=$ Annual average solar radiation on tilted panels (shadings not included) $=1606 \mathrm{kWh} / \mathrm{m} 2 /$ year in Egypt, $\boldsymbol{P R}=$ Performance ratio, coefficient for losses (range between 0.5 and 0.9 , default value $=0.75$ ). The total energy produced is:

$$
E=A * r * H * P R=448 * 20 \% * 1606 * 0.75=\mathbf{1 0 7 9 2 3 . 2} \mathbf{~ k W h} / \mathbf{y r} \text {. }
$$

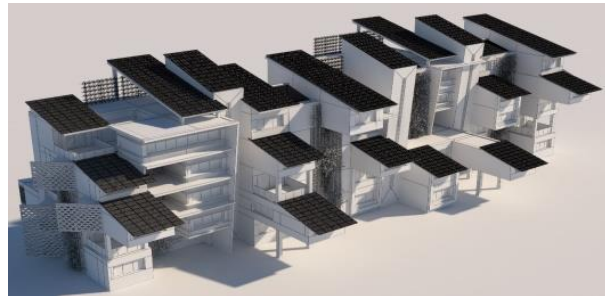

Fig. 14. (PV) panels covering inclined roof \& south façade, Source: Author

By this medication, solar techniques coverd $44 \%$ of the remained total energy needs, and $56 \%$ of building energy is required to be coverd.

\subsubsection{Wind Turbines techniques}

Extra energy production method is needed. Micro wind turbines (MWT) were chosen for their competetive cost to the conventional turbines of equivalent power output. The choosen type is $25 \mathrm{~cm}$ diameter wind turbine gather in rows, each row consist of 8 MWT and each 6 rows are connected togather, installed on the roof by metal web, in a $5 \mathrm{~m} / \mathrm{s}$ each MWT generate $131 \mathrm{kWh} / \mathrm{yr}$ [32], and in $13 \mathrm{~m} / \mathrm{s}$ avrage wind speede in Cairo it will generate $340.6 \mathrm{kWh} / \mathrm{yr}$ So, the total energy produced from an array of 408 microwind turbines added to the building in $13 \mathrm{~m} / \mathrm{s}$ wind speede $=408 * 340.6=138964.8 \mathbf{~ k W h} / \mathbf{y r}$.

In this case micro wind turbines cover $\mathbf{5 6 . 7 \%}$ of the total office building prototype energy needs. (Fig.36) 


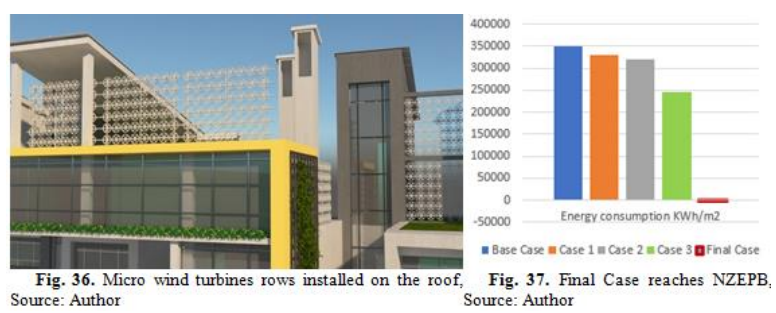

Virtually, (PV) cells and wind turbines cover the building energy needs. Mathematically, the office building prototype becomes Zero Energy Public Building (fig.37). And respectively, the proposed design methodology succeeds to reach ZEPB, or at least near it if we add non-studied factors - such as electricity used in energy production.

\section{Final discussion \& conclusions}

Remarking its main target to find out; an Intensive methodology to design Near Zero Energy Public Building in Egypt, the research finds the followings:

- The proposed intensive methodology must begin its task by applying the passive design criteria and coincides the planed functions of the building from the beginning.

- The following step is adopting energy reduction strategies to the design process. Simulation programs are strongly recommended in this step to test several alternatives and their effect on energy reduction.

- Proposed alternatives can be prompted by considering building Envelop and its elements and/or service systems and their elements.

- Afterward, the chosen simulation programme proceeds with the proposed alternatives.

- After comparing results and calculations, optimum alternative is chosen, and total building's energy needs are stated.

- As its last step, the intensive methodology supports using renewable energy techniques to produce energy and cover part or all the remaining energy needed.

The research case study applies the proposed intensive design methodology with its three phases. An office building prototype is designed, modeled and tested. The design builder software is calibrated then used to calculate and compare energy consumption along the design process. Reduction strategies used in this case study reduce energy consumption by $28 \%$ comparable to the base case. Solar panels and wind turbines are integrated afterward to produce $44 \%$ and $56.7 \%$ respectively to meet the remaining energy demand. Mathematically, the office building prototype reaches zero energy consumption if factors beyond this research scope are neglected.

The suggested Intensive methodology to design NZEPB recommends using its flow chart (fig. 38) when targeting design near zero energy public building in Egypt. 
Rania Fouad Ismail et al., An intensive methodology for designing near zero energy ..........

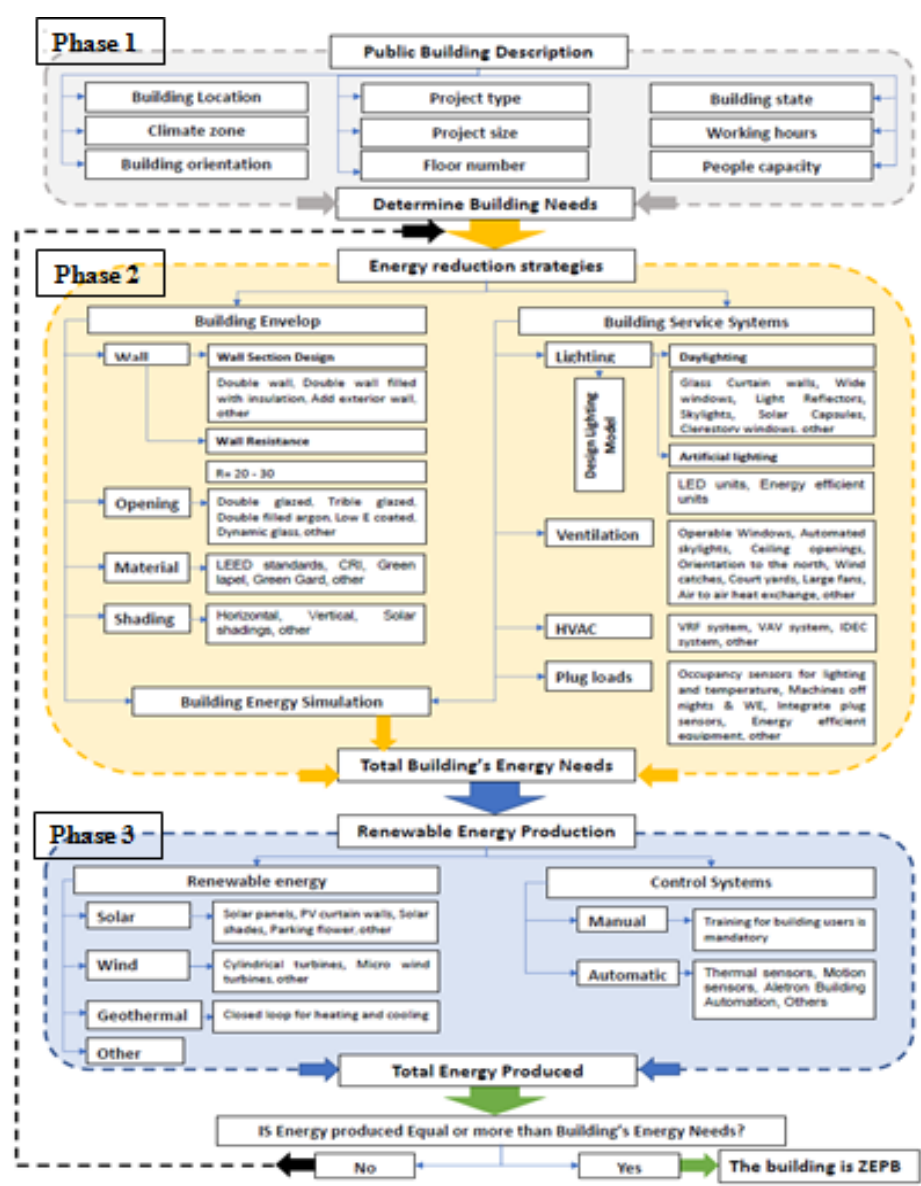

Fig. 15. The proposed intensive methodology for designing NZEPB design, Source: Author

\section{REFERENCES}

[1] Sbci, U., Buildings and climate change: a summary for decision-makers,p. 1-62. Paris: United Nations Environ. Program. Sustain. Build. Clim. Initiat, (2009).

[2] Tea, F. L., Mainstreaming Energy Efficiency Code in Developing Countries. global Experiences and Lessons from Early Adopters, World Bank, p. 204, (2011).

[3] L. Pérez-Lombard, A review on buildings energy consumption information, Energy Build, vol. 40, p. 394-398, (2008).

[4] S, C., How Building Technologies Contribute to Net-Zero Energy Design, Building Design and Construction, (2011).

[5] https://bizfluent.com/info-7834283-types-public-buildings.html, (2017).

[6] Consultation, Display Energy Certificates: current regime and how it could be streamlined and improved. https://www.designingbuildings.co.uk/wiki/Public building definition, (2015).

[7] Majd Fayyad, J. J., Defineing Nearly Zero Energy Buildings in the UAE-2017, UAE: Emirates Green Building Counci, (2017).

[8] DOE, National Renewable Energy Laboratory (NREL), A Common Definition for Zero Energy Buildings, USA: U.S Department of Energy, Energy Efficiency and Renewable Energy, (2015).

[9] California Energy Commission,. Revised Zero Net Energy (ZNE) Definition, California: IEPRWorkshop, California Energy Commission, (2011).

[10] SNEBRN, Smart Net-Zero Energy Buildings Strategic Research Network, s.l.: www.solarbuildings.ca. (2012). 
JES, Assiut University, Faculty of Engineering, Vol. 48, No. 3, May 2020, pp. 447-467

[11] https://ec.europa.eu/energy/en/topics/energy-efficiency/buildings/nearly-zero-energy-buildings, (2019).

[12] William W., B., Architecture and systems ecology: Thermodynamic principles of environmental buildings design, in three parts. New York: Routledge, (2016).

[13] https://gharpedia.com/importance-of-building-orientation-in-architecture, 2019.

[14] Hootman, T., Net Zero Energy Design[M], First Edition. Canada: JOHN WILEY \& Sons, Inc. (2013).

[15] www.yourhome.gov.au/passive-design, 2019.

[16] Li Yuana, Yingjun R., Guang Y., Fan F., Zhengwei L., Analysis of Factors Influencing the Energy Consumption of Government Office Buildings in Qingdao. China: Elsevier Ltd, (2016).

[17] Methodology for calculating the energy performance of buildings, Minister of Economic Affairs and Communications regulation, (2014).

[18] https://newbuildings.org/wp-content/uploads/2017/03/CPUC_435Indio.pdf, (2018).

[19] Luqman M, Ahmad SR, Khan S, Ahmad U, Raza A, and Akmal F., Estimation of solar energy potential from rooftop of Punjab government servants cooperative housing society Lahore using GIS. Smart Grid andRenewable Energy, (2015).

[20] Ehsanul K., Pawan K. , Sandeep Kumarc , Adedeji A. Adelodund , Ki-Hyun Kim., Solar energy: Potential and future prospects. ELSEVIR, Renewable and Sustainable Energy Reviews, (2017).

[21] Askari M. Bagher, Mirzaei M. Abadi Vahid, Mirhabibi Mohsen, Types of Solar Cells and Application. American Journal of Optics and Photonics. (2015).

[22] Bedri Kekezoğlu, Muğdeşem Tanrı̈̈ven, Ali Erduman, A New Wind Turbine Concept: Design and Implementation. Acta Polytechnica Hungarica, pp. Vol. 12, No. 3. (2015).

[23] https://www.climatetechwiki.org/technology/building-integrated-wind-turbines, (2019).

[24] http://www.wbdg.org/resources/smart-controls, (2019).

[25] https://newbuildings.org/resource/getting-to-zero-database/ (2019)

[26] Sadik Yigit, B. O., A simulation-based optimization method for designing energy efficient buildings. Energy and Buildings, Volume 178, pp. 216-227, (2018).

[27] Rania Ismail, Gehad Salama, Maha Elgohary, Soha Elgouhary, Towards Zero Enegy Resedential Unit in Egypt. Cairo, Architectural Department, Cairo University, (2019).

[28] https://www.facilitiesnet.com/hvac/article/Four-pipe-Fan-Coil-Unit-Systems-Is-It-Rightfor-Your-Facility--17470, (2019).

[29] ASHRAE, ASHRAE Handbook of Fundamentals, (2017).

[30] Apricus Solar, Apricus Solar Collector Installation and Operation Manual, (2014).

[31] https://photovoltaic-software.com/principle-ressources/how-calculate-solar-energy-powerpv-systems, (2019).

[32] https://inhabitat.com/micro-wind-turbines-small-size-big-impact/, (2019).

[33] https://www.climatetechwiki.org/sites/climatetechwiki.org /files/images/extra/buildingintegrated_wind_wind_in city.jpg (2019)

[34] Bedri., Muğdeşem T., Ali E., A New Wind Turbine Concept: Design and Implementation, Acta Polytechnica Hungarica, Vol. 12, No. 3, (2015).

[35] https://www.dictionary.com/browse/r-value, (2019).

[36] https://www.dexma.com/study-energy-performance-of-europes-buildings/, (2019).

[37] https://focussolar.en.made-in-china.com, (2019). 


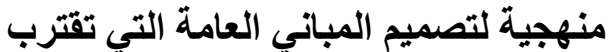

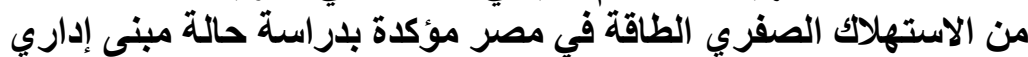

ملخص

يستهلك قطاع البناء حاليا 40٪ من إجمالي استهلاك الطاقة في جميع أنحاء العالم. ويزيد هذا الرقم في مصر ليصل إلى 5 إلى

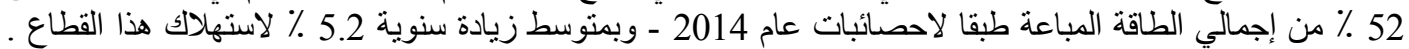

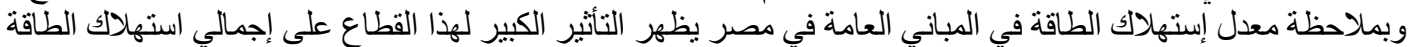

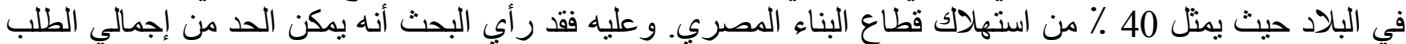

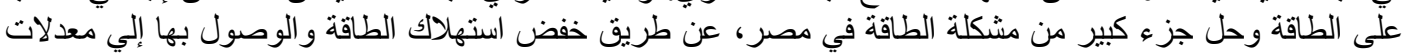

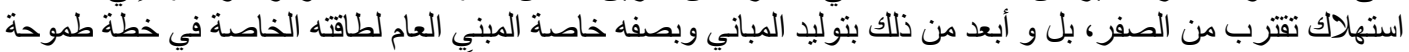

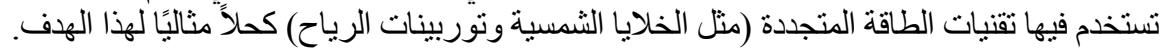

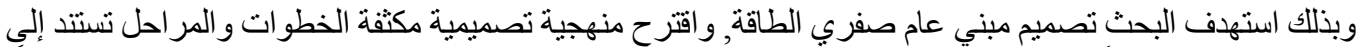

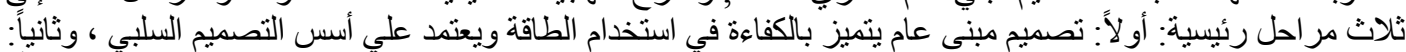

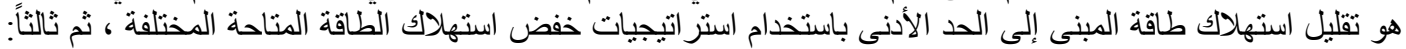

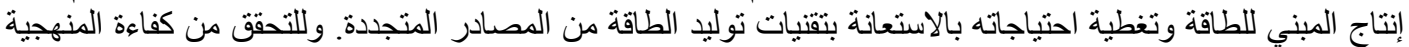

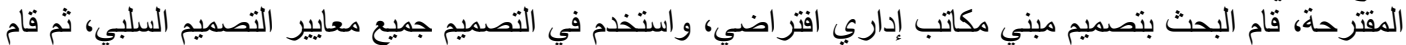

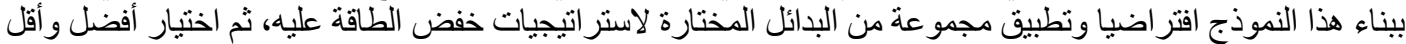

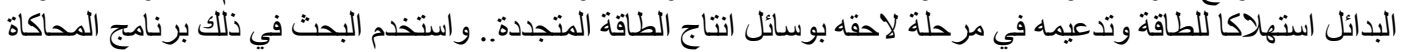
لحساب ومقارنة استهلاك طاقة المبنى في المر احل الثنات الناث المتتالية.

وفي نهاية البحث وبعد تطبيق المنهجية المقترحة علي النموذج الافنر اضي الذي تم تصميمه خصيصا لهذا الغرض،

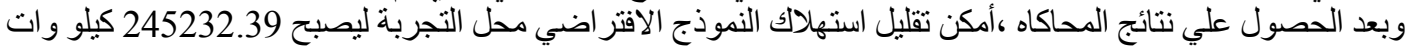

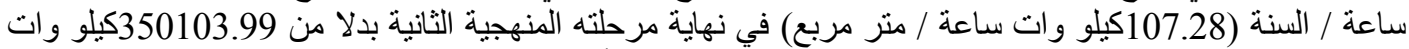

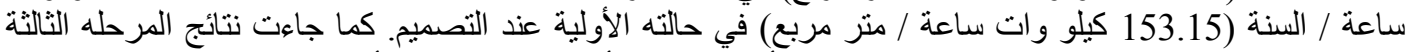

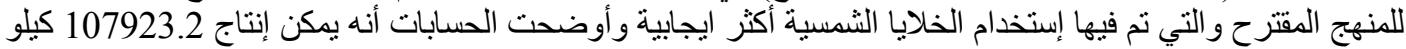

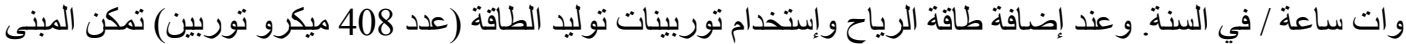

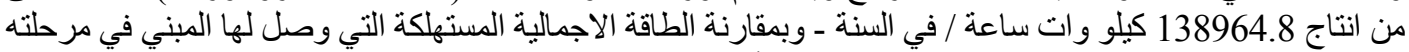

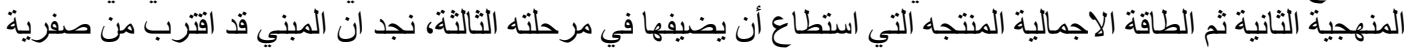

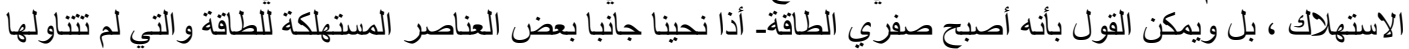

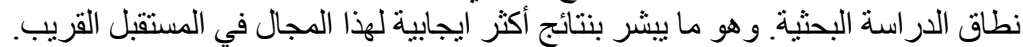

